\title{
Okul Öncesi Dönem Çocuklarının Annelerinin İstismar Düzeyleri, Ebeveyn Tutumları ve Çocuklarının Davranış Problemleri Arasındaki İlişki ${ }^{1}$
}

\author{
DOI: 10.26466/opus.507909 \\ *
}

\author{
Pınar Bağçeli Kahraman ${ }^{*}-$ Ayşe Çubukçu ** \\ * Dr. Öğr. Üyesi, Bursa Uludağ Üniversitesi, Eğitim Fakültesi, Bursa, Türkiye \\ E-Posta: pinarbag@uludag.edu.tr \\ ORCID: $\underline{0000-0002-0551-7741}$ \\ ** Bursa Uludağ Üniversitesi, Eğitim Bilimleri Enstitüsü, Bursa, Türkiye \\ E-Posta: aysecubukcu@gmail.com \\ ORCID: $\underline{0000-0002-3704-8994}$
}

\begin{abstract}
$\ddot{O} z$
Okul öncesi dönemde çocukların davranış sorunlarının özellikle davranışlarıyla bağlantılı olduğu düşünülmektedir. Bu durumdan yola çıkarak okul öncesi dönemde çocukların davranış sorunlarının annelerin tutumları ve istismar düzeylerinden ne düzeyde etkilendiğinin belirlenmesinin davranış sorunlarının en az düzeyde ve erken dönemde önüne geçilebilmesine katkı sağlayacağı düşünülmektedir. Bu araştırmanın amacı da okul öncesi dönem çocuğuna sahip annelerin anne tutumları ve istismar düzeylerinin çocukların davranış sorunların ne düzeyde yordadığın belirlemektir. Bu amaç doğrultusunda bu araştırmada ilişkisel araştırma kullanılmıştır. Araştırmanın çalışma grubunu, Bursa ili merkez ilçelerine bağhl yedi farklı resmi okul öncesi eğitim kurumunda öğrenim görmekte olan 5-6 yaş grubu çocuklar arasindan uygun örnekleme yöntemi ile seçilmiş toplam 208 çocuk ve bu çocukların anneleri oluşturmaktadır. Araştırmada kişisel bilgi formu, Okul Öncesi Davranış Sorunları Tarama Ölçeği (Kanlıkılıçer, 2005), İstismar Farkındalık Ölçeği: Ebeveyn Formu (Pekdoğan, 2017) ve Ebeveyn Tutum Ölçeği (Demir ve Şendil, 2008) kullanılmıştır. Annelerin istismar düzeyleri ve tutumlarının, davranış problemlerini ve alt boyutlarını en iyi açıklayan değişkenleri belirlemek amacıyla çoklu hiyerarşik regresyon analizi yapılmıştır. Araştırma sonucunda çocukların davranış problemleri toplamı ile annelerin istismar farkındalı düzeyleri ve izin verici tutuma sahip olmalar arasinda pozitif yönlü, annelerin demokratik tutuma sahip olmaları arasında ise negatif yönlü bir ilişki bulunduğu saptanmıştır. Ayrıca izin verici tutum gösteren ebeveynlerin, çocuklarının davranış problemleri, kavgacı-saldırgan olmaları, aşırı hareketli ve dikkatsiz olmaları arasında ilişki bulunduğu belirlenmiştir. Araştırma sonucunda demokratik tutumun çocukların kavgacı-saldırgan olmaları ile negatif yönlü ilişkiye sahip olduğu da saptanmıştır. Annenin istismar düzeyi ile çocuklarının aşırı hareketli ve dikkatsiz olmaları arasında pozitif yönlü iliş̧i belirlenmiştir. Yapılan bu araştırma sonucunda her ne kadar izin verici tutumun davranış sorunları ile pozitif yönlü ilişkisi olduğu belirlenmiş olsa da ilişki oranının düşük olduğu da belirlenmiştir.
\end{abstract}

Anahtar Kelimeler: Çocuk istismarı, Ebeveyn tutumları, Davranış problemleri, Okul öncesi dönem

\footnotetext{
${ }^{1}$ Bu çalışma V $V^{\text {th }}$ Uluslararası Avrasya Eğitim Araştırmaları Kongresinde bildiri olarak sunulmuştur.
} 


\title{
The Relation Between the Abuse Levels of Mothers, Parental Attitudes and Behavioural Problems of Children \\ *
}

\begin{abstract}
It is thought that within the preschool period especially the behaviours of the mothers cause the children's behavioural problems. From this point of view it is thought that the determination of the relation between the children's behavioural problems and mothers' attitudes with abuse levels will contribute to the decrease of the behavioural problems and prevent these behaviours in early period. Within the study it is aimed to determine the relation between the children's behavioural problems and the attitudes of the mothers who has preschool children with their abuse levels. From this point of view the purpose of this research is to determine how the attitude of the mothers and the abuse levels predict the children's behavioural problems. In this study correlational research was used. The study group of the research consists of totally 208 children, who were chosen with the appropriate sampling method among children at the age of 5-6 and attend seven different public preschools in the central districts of Bursa city, and the mothers of these children. Within the research personal information form, "Preschool Behavioural Problems Scanning Scale", "Abuse Awareness Scale: Parent Form" and "Parent Attitude Scale" were used. In order to determine the variables that determine the mothers' abuse levels and attitudes, the behavioural problems which are dependent variable and their sub dimensions ideally multi hierarchical regression analysis was performed. As a result of the research it was determined that there was a positive relation between children's behavioural problems and mothers abuse levels along with their having permissive attitude; and negative relation between mothers' having democratic attitude. Also as a result of the research; it was determined that the parents, who have permissive attitudes, affect the children's behavioural problems positively, being combative-aggressive, hyperactive and inattentive. In addition as a result of this research it was determined that democratic attitude has effect negatively on the children's being combative-aggressive. It was found that mother's abuse level has positive effect on the children's being hyperactive and inattentive. As a result of this research although it is determined that permissive attitude has positive effect on behavioural problems it is seen that the effect rate is low.
\end{abstract}

Keywords: Child abuse, Parents' attitude, Behavioural problems, Preschool period 


\section{Giriş}

Birey dünyaya geldiği andan itibaren sosyal ve fiziki bir çevre içine girmekte ve bir uyum süreci başlamaktadır. Okul öncesi dönemi içine alan bu süreçte, çocuğun biyolojik, fizyolojik ve duygusal gereksinimlerinin karşılanamaması çocuğun gelişimsel olarak dezavantajlı duruma düşmesine sebep olmakta ve çocukta davranış problemlerinin ortaya çıkmasına zemin hazırlamaktadır (Çebi, 2017; Tarkoçin, 2014). Davranış problemleri çocuğun ortaya koyduğu duygusal ve davranışsal sorunlar olarak tanımlanmakta; öfke, saldırganlık, hiperaktivite ve dikkat eksikliği gibi davranış bozuklukları dışa yönelim; ağlamaklı, endişeli olmak, içe kapanıklık gibi davranış bozuklukları ise içe yönelim olarak belirtilmektedir (Caldarella ve Merrell, 1997; Rusby, 1998). Bu sorunlar üzerinde etkili olan en önemli faktörler ise çocuğun çevresindekilerle ve özellikle ebeveynleriyle kurduğu olumsuz ilişkilerdir (Budak, 2017). Yapılan araştırmalar, sıfır-bir yaş döneminde yaşanan aile içi sorunların çocuğun dışa yönelim sorunlarını belirlediğini; ikinci ve üçüncü yaşta yaşanan sorunların ise hem içe yönelim hem de dışa yönelim sorunlarını belirlediğini ve annenin duyarsız olmasının çocuğun dışa yönelimli davranış sorunları göstermesine yol açtığını belirlemişlerdir (Büküşoğlu ve Aysan Erermiş, 2001; Fluori, Tzavidis ve Kallis, 2009). Üç ve dört yaştan itibaren yaşanan sorunların da ergenlik döneminde veya çocukların ileriki yaşamlarında da devam ettiği ve bu sorunların kalıcı olma ihtimalinin yüksek olduğu belirtilmektedir (Derman-Taner ve Başal, 2013). Davranış problemleri aile içinde yaşanan olumsuzluklar, yanlış ebeveyn tutumları, kalıtsallık gibi pek çok faktörden de etkilenmektedir. Anne-baba arasında yaşanan problemlerin çocuğa yansıtılması, aşırı koruyucu ve otoriter ebeveyn tutumlarının sergilenmesi çocuğun özgüveninin sarsılmasına, çaresiz ve yalnız hissetmesine sebep olmakta ve bu süreç devam ettiğinde çocukta oluşmaya başlayan bu hisler davranış problemlerinin ortaya çımasına sebep olmaktadır (Köyceğiz ve Özbey, 2018).

Bronfenbrenner'in (1979) Ekolojik Kuramına göre; çocuk gelişimsel süreçte, kardeş, ebeveyn, dede-nine, hayvanlar, okul ve arkadaşlar gibi karmaşık sosyal bir çevre içinde gelişmektedir. Bronfenbrenner'e göre çocuğun gelişimi çevresel sistemin etkisini yansıtmaktadır. Bu çevresel sistem- 
ler mikrosistem, mezosistem, egzosistem, makrosistem ve kronosistem olmak üzere beş halkadan oluşmaktadır. İlk halkayı oluşturan mikrosistemde anne-babaların çocuklarına gösterdiği demokratik, otoriter, izin verici ya da aşırı koruyucu tutumların çocuk üzerinde önemli etkiler bıraktığ1 belirtilmektedir (Berk, 2009; Erkan, 2010; Santrock, 2015; Özgün, 2013; Uyanık Balat, 2007). Baumrind (1971) anne baba tutumlarını otoriter, demokratik, ihmalkar ve hoşgörülü olmak üzere dört başlıkta ele almıştır. Demokratik tutum, çocuğa da söz hakkı verilen, bağımsızlık ve sevgi temellerine dayandırılmıs tutum olarak belirtilmektedir ve eşit ve paylaşımcı davranışların hâkim olduğu tutumdur. Otoriter tutum ise kural ve emirlerin kullanıldığı, güvensizliğin yer aldığı ve çocuklara söz hakkı verilmeyen tutum olarak karşımıza çıkmaktadır. Araştırmalar otoriter tutumla yetişen çocukların saldırgan davranışlar gösterdiği yönündedir (Benzies, Keown, ve MagillEvans, 2009; Huntsinger ve Rose, 2009). Aşır1 hoşgörülü tutumda ise ebeveynler çocuklarının her istediğini yapma eğilimindedirler. Çocuğun kendi davranışlarını kontrol edebilmeyi öğrenememesine ve benmerkezci olmasına sebep olabilmektedirler. İhmalkar tutumda çocuklar her kararı kendileri almakta, ebeveynler koşulsuz olarak çocuğun her davranışını kabul ederek ihmalkâr davranış sergilemektedirler (Baumrind, 1971). Aşırı hoşgörü de, çocuğun bencil olmasına ve sosyal çevreyle uyumunun zayıflamasına neden olmaktadır (Baumrind, 1971). Anne ve babaların çocuklarına gösterdikleri davranışlar çocukların kişiliklerine ve sosyal davranışlarına etki etmekte ve sağlıklı bireylerin yetişmesi öncelikle bu tutumlara bağlı olarak gerçekleşmektedir (Aydoğdu ve Dilekmen, 2016; Kaya, Bozaslan ve Genç, 2012). Ebeveynin gösterdiği tutum ve davranışlar yaşanılan toplumun kültür yapısı, anne babanın mesleği, öğrenim durumu, aile içi ilişkiler gibi birçok faktörden etkilenmektedir (Özerk, 2006; Şahin ve Özyürek, 2008).

Çocuğun gelişimini ve büyümesini olumsuz yönde etkileyen davranış ve eylemlerin her biri çocuk istismarına temel oluşturabilmektedir. Çocuklar içinde bulundukları sosyal çevrelerinde çeşitli tehlikeli durumlar ve problemlerle karşılaşmaktadırlar. Bu tehlikeler arasında en tahrip edici olanı ise çocuk istismarıdır ve çocuk istismarı dünya genelinde bir problem olarak karşımıza çıkmaktadır (Topçu, 2009; Levey ve ark., 2017; Yalçın, Koçak ve Duman, 2014). Dünya Sağlık Örgütü (WHO, 2002) çocuk istismarını, çocuğun sosyal, duygusal ve fiziksel gelişimi ile sağlığını 
olumsuz yönde etkileyen bilerek veya bilmeyerek bir yetişkin ya da toplum tarafından yapılan davranışlar olarak belirtmektedir. Çocukların öncelikle temel gereksinimlerinin giderilmesi ve desteklenmesi anne ve babalarına ya da onların sorumluluğunu üstlenen kişilere bağlıdır. Ancak tüm çocuklar aynı derecede olanaklara sahip olamamakta, bedensel, zihinsel ve ruhsal gelişimleri yeterli düzeyde gelişememekte ve/veya çeşitli yetersizliklere sahip olabilmektedirler (Topçu, 2009). Çocuğun istismara maruz kalması, çocuk üzerinde davranışsal ve psikolojik bozukluklar meydana getirmekte ve kalıcı hasarlara yol açabilmektedir (Yılmaz ve ark., 2003). İstismarın her türünün çocuklar üzerinde yadsınamayacak düzeyde olumsuz etkileri olmaktadır. İstismara maruz kalan çocuklarda kaygı, depresyon, kişilik bozukluğu gibi psikolojik problemlerin yanı sıra fiziksel ve zihinsel birçok sorunla da karşılaşılmaktadır (Bernard vanLeer Vakfı, 2014). Çocuk istismarı, genellikle çocuğun tanıdığı ve ailesi, aile yakınları, öğretmenler, komşular gibi yakınında yer alan kişiler tarafından uygulanmaktadır (Gürhan, 2015; Leetch ve Woolridge, 2013). Yapılan bir araştırma sonucunda, araştırmaya katılan tüm çocukların değişen oranlarda da olsa istismara uğradıkları ve bu davranışların en önemli kaynaklarının aile üyeleri, öğretmenler ve akranlar olduğu belirlenmiştir (Türkiye' de Çocuk İstismarı ve Aile İçi Şiddet Araştırması, 2010). Bu açıdan aile, çocukların kendini en fazla güvende hissedeceği yer olmakla birlikte, en çok risk altında kaldıkları yerdir. Nitekim Demir, Karabay ve Ası (2017) beş yaş çocuklarının sosyal duygusal uyumları ile ebeveyn tutumlarını araştırdıkları çalışmada aşırı koruyucu, otoriter ve izin verici tutumla yetişen çocukların sosyal duygusal uyumlarının düşük olduğunu ifade etmektedirler. Yurduşen ve arkadaşlarının (2013) yapmış oldukları araştırmada ebeveyn tutumlarının çocuklarının duygusal gelişimi ve davranış problemleri ile yakından ilişkili olduğunu saptanmıştır. Türkiye'de yapılan araştırmalar incelendiğinde; ebeveynlerin çocuk yetiştirme tutumlarının farklı değişkenlerle ele alındığı (Alabay, 2017; Atabey, 2017; Cenk-Sarı ve Demir, 2015; Demir, Karabay ve Ası, 2017; Işıkoğlu Erdoğan, Yoleri ve Tetik, 2017; Özbey ve Alisinanoğlu, 2009; Özyürek ve Şahin, 2005, Şendil ve Demir, 2008); okul öncesi dönemde davranış sorunları üzerine yapılan (Akman, Baydemir, Akyol, Arslan, ve Kükütçü, 2010; Alisinanoğlu ve Kesicioğlu, 2010; Derman- Taner, Başal, 2013; İkiz, Mete, Ekinci Vural, 2016; 
Karg1 ve Erkan, 2004) ve ebeveynlerin istismar farkındalıkları ile ilgili yapılan (Kara Doruk, 2012;Kaya ve Çeçen-Eroğul, 2015; Keser, Odabaş ve Elibüyük, 2010; Pekdoğan,2017; Pekdoğan ve Kanak, 2017; Türkiye' de Çocuk İstismarı, 2010; UNICEF, 2010; Yalçın, Koçak, ve Duman, 2014) çeşitli çalışmaların olduğu belirlenmiştir. Yabancı literatür incelendiğinde ise; çocuk yetiştirme tutumları ile davranış problemleri arasındaki ilişkiyi(Gimpel, Peacock ve Holland, 2003; Grusec, Danyliuk, Kil ve O'Neill, 2017; Huntsinger ve Rose, 2009; Park, Johnston, Colalillo ve Williamson, 2018; Waller, Gardner, Hyde, Shaw, Dishion ve Wilson, 2012) ve ebeveynlerin istismar düzeyleri ile istismara yol açan etkenleri (Benzies, Keown ve Magill-Evans, 2009; Levey, 2017; Milaniak ve Widom, 2015; Seng ve Prinz, 2008; Svensson, Bornehag ve Janson, 2011) inceleyen çeşitli araştırmaların olduğu görülmektedir. Yapılan bu çalışmada ise annelerin istismar düzeylerinin ve ebeveyn tutumlarının çocukların davranış sorunları ile ilişkisinin incelenmesi amaçlanmıştır. Ülkemizde çocukları ile en fazla ilgilenen ve eğitiminden sorumlu olan kişinin daha çok anne olarak görüldüğü düşüncesinden yola çıarak sadece anneler ile çalışılmıştır. Okul öncesi dönemde özellikle annelerin göstermiş oldukları davranışların çocuklarda davranış sorunlarına yol açtığı düşünülmektedir. Bu açıdan çocukların davranış sorunlarının annelerin tutumları ve istismar düzeyleri ile ilişkisi olup olmadığının belirlenmesinin çocuklarda davranış sorunlarının en az düzeyde görülmesine, annelerde söz konusu sorunlarla ilgili farkındalık yaratacağ1 ve bu sorunların erken dönemde önüne geçilebilmesine katkı sağlayacağı düşünülmektedir. Dolayısıyla bu araştırmada okul öncesi dönem çocuğuna sahip annelerin ebeveyn tutumları ve istismar düzeylerinin çocukların davranış sorunları ile olan ilişkisinin incelenmesi amaçlanmaktadır. Bu amaç doğrultusunda aşağıdaki sorulara yanıt aranmıştır?

1. Okul öncesi dönem çocuklarının davranış sorunları ile annelerinin ebeveyn tutumları ve istismarları ne düzeydedir?

2. Okul öncesi dönem çocuklarının davranış sorunları ile annelerin ebeveyn tutumları ve istismar düzeyleri arasında ilişki var mıdır?

3. Okul öncesi dönem çocuklarının davranış sorunlarını annelerin ebeveyn tutumları ve istismar düzeyleri yordamakta mıdır? 


\section{Yöntem}

Okul öncesi dönem çocuklarının annelerinin istismar düzeyleri ile ebeveyn tutumlarının çocukların davranış problemleri arasında ilişki olup olmadığını belirlemek amacıyla yapılan bu araştırmada betimsel tarama modelinde ilişkisel tarama yöntemi kullanılmıştır. İlişkisel araştırma değişkenler arasındaki ilişkiyi saptamayı amaçlamaktadır (Büyüköztürk, Çakmak, Akgün, Karadeniz ve Demirel, 2012; Sönmez ve Alacapınar, 2016).

\section{Araştırmanın Çalışma Grubu}

Araştırmanın çalışma grubunu, Bursa ili merkez ilçelerine bağlı yedi farklı okul öncesi eğitim kurumunda öğrenim görmekte olan 60-72 aylık çocuklar arasından uygun örnekleme yöntemi ile seçilmiş toplam 208 çocuk ve bu çocukların anneleri oluşturmaktadır. Bu çocukların \%52,4'ü $(\mathrm{n}=109) \mathrm{kız}, \% 47,6^{\prime} \mathrm{s} 1$ (n=99) erkektir. Çocukların \%26,4'ü (n=55) 2013, $\% 73,6$ 's1 (n=153) 2012 doğumludur. Çocukların \%46,2'si (n=96) daha önce okul öncesi eğitim almamış olup, \%53,8'i ( $n=112)$ daha önce okul öncesi eğitim almıştır. Annelerin \%11,5'i (n=24) 41 ve üzeri, \% 62'si (n=129) 3140 ve \% 26,4'ü (n=55) 20-30 yaş aralığındadır. Ayrıca annelerin \%10,6's1 $(\mathrm{n}=22)$ ilkokul, \%11,5'i (n=24) ortaokul, \%33,7'si (n=70) lise, \%12,5'i (n=26) önlisans, \%31,7'si (n=66) lisans mezunudur.

\section{Veri Toplama Araçları}

Araştırmada kişisel bilgi formu, Okul Öncesi Davranış Sorunları Tarama Ölçeği (Kanlıkılıçer, 2005), İstismar Farkındalık Ölçeği: Ebeveyn Formu (Pekdoğan, 2017) ve Ebeveyn Tutum Ölçeği (Demir ve Şendil, 2008) kullanılmıştır.

Okul Öncesi Davranış Sorunları Tarama Ölçeği: Okul öncesi dönem çocuklarının davranış sorunlarını değerlendirebilmek için Behar (1976: Akt. Kanlıkılıçer, 2005) tarafından geliştirilen "Preschool Behavior Questionnaire" Kanlıkılıçer (2005) tarafından Türkçe'ye uyarlanmıştır. Ölçek, “(0) doğru değil”, "(1) bazen doğru” ve "(2) kesinlikle doğru” şeklinde 
puanlanmaktadır. Kanlıkılıçer (2005) tarafından Cronbach Alpha iç tutarlılık katsayısı 92 olarak saptanmıştır. Yapılan faktör analizi sonucunda, ölçekte Endişeli - Ağlamaklı Olmak (14 madde), Kavgacı - Saldırgan Olmak (12 madde) ve Aşırı Hareketli- Dikkatsiz Olmak (4 madde) şeklinde üç alt boyut belirlenmiştir. Ölçek öğretmenin çocuğu değerlendirmesini kapsamaktadır. Bu araştırma kapsamında Kavgacı-Saldırgan Olmak alt boyutunun Cronbach Alfa güvenirlik katsayısı .81, Endişeli-Ağlamaklı olmak alt boyutunun güvenirlik katsayısı .67, Aşırı Hareketli-Dikkatsiz Olmak alt boyutunun güvenirlik katsayısı da .77 olarak bulunmuştur.

İstismar Ölçeği Ebeveyn Formu: Pekdoğan (2016) tarafından 4-6 yaşındaki çocuklarına yönelik olarak ebeveynlerin istismar düzeylerini belirlemeyi amaçlayan bu ölçek, tek boyutlu olup, beşli likert tipinde hazırlanmış 18 maddeden oluşmaktadır. Ölçek, "(1) hiç katılmıyorum ", "(2) katılmıyorum ", "(3) orta düzeyde katılıyorum ", "(4) katılıyorum " ve "(5) tamamen katılıyorum" şeklinde puanlanmaktadır. Örnek olarak "Çocuğum olumsuz bir davranış sergilediğinde fiziksel ceza uygularım." maddesi verilebilir. Ölçme aracından en yüksek 90, en düşük 18 puan alınabilmektedir. Düşük düzeyde istismar 18-42 puan aralığında, orta düzeyde istismar 42-66 puan aralığında, yüksek düzeyde istismar ise 6690 puan aralığında yer almaktadır. Ölçeğin test tekrar test korelasyonu toplam r= 94 olarak; 18 maddenin Cronbach Alfa iç tutarlılı̆̆ ise .98 olarak belirlenmiştir. $\mathrm{Bu}$ araştırmada Cronbach Alfa güvenirlik katsayısı .71 olarak belirlenmiştir.

Ebeveyn tutum ölçeği (ETÖ): Ebeveyn Tutum Ölçeği Karabulut Demir ve Şendil (2008) tarafından 2-6 yaş arası çocuğu olan ebeveynlerin çocuk yetiştirme tutumlarını belirlemek için geliştirilmiştir. Ölçek beşli likert tipinde olup; maddeler "(5) her zaman böyledir", "(4) çoğunlukla böyledir", "(3) bazen böyledir", "(2) nadiren böyledir" ve "(1) hiçbir zaman böyle değildir" olarak derecelendirilmiştir. Ebeveyn Tutum Ölçeği ise 46 maddeden oluşmakta olup otoriter, demokratik, izin verici ve aşırı koruyucu olarak dört alt boyuttan oluşmaktadır. Beşli likert tipinde hazırlanmıştır. Alt boyutların Cronbach alfa değerleri otoriter tutum .76, demokratik tutum .83 , izin verici tutum ise .74 ve aşırı koruyucu tutum .75 
olarak belirlenmiştir. Bu araştırma da Cronbach Alfa değerleri izin verici tutum .83 , koruyucu tutum .87 , otoriter tutum .91 , demokratik tutum .96 olarak saptanmıştır.

\section{Veri Toplama Süreci}

Araştırma, veri toplama sürecine geçilmeden önce etik kurallar ve ilkeler doğrultusunda incelenmesi için Uludağ Üniversitesi Senatosu Etik Komisyonu'na gönderilmiştir. Onay alındıktan sonra İl Milli Eğitim Müdürlüğünden izin alınmış ve araştırma sürecine katılacak okullar, okul müdürleri ile görüşme sağlanarak belirlenmiştir. Okullar Bursa ili merkez ilçelerinde yer alan öncelikle ulaşımı kolay olan okullar arasından belirlenmiştir. Gönüllü olan öğretmenlere, araştırmanın amacı ve önemine yönelik bilgi verildikten sonra velilere ulaştırılması amacıyla ölçekler dağıtılmıştır. Velilere araştırmanın gönüllülük esasına dayandı̆̆ı, çocuklarının da değerlendirileceği ve araştırmadan elde edilen bilgilerin gizli tutulacağı bilgisi de ulaştırılmıştır. Gönderilen 367 ebeveyn tutum ölçeği ile istismar ölçeklerinden 208'i geri (\%57) dönmüştür. Velilere dağıtılan ölçekler 2 hafta içerisinde geri toplanmıştır. Geri dönüş yapan velilerin çocukları için öğretmenlerin davranış problemlerini değerlendirmesi istenmiştir.

\section{Verilerin Analizi}

Okul öncesi dönem çocuklarının annelerinin istismar farkındalık düzeylerinin ve tutumlarının çocukların davranış problemleri üzerindeki yordayıcı etkisini belirlemek amacıyla yapılan bu araştırmada betimsel analiz yöntemlerinden faydalanılmıştır. Verilerin analiz edilmesi amaciyla SPSS 22 (Statistical Paket of Social Science) paket program kullanılmıştır.

Annelerin istismar düzeyleri ve tutumlarının, bağımlı değişken olan davranış problemlerini ve alt boyutlarını en iyi açıklayan değişkenleri belirlemek amacıyla çoklu hiyerarşik regresyon analizi yapılmıştır. Ölçeklerden ve alt boyutlardan alınan puanların normal olup olmadığ basıklık (Kurtosis) ve çarpıklık (Skewnes) katsayılarına göre değerlendirilmiş ve Ebeveyn Tutumları Ölçeği Demokratik Ebeveyn Tutumu ile 
Davranış Problemleri alt boyutlarından Kavgacı-Saldırgan Olmak ve Endişeli-Ağlamaklı Olmak puanlarının normallik göstermediği belirlenmiştir. $\mathrm{Bu}$ nedenle dağılımları normalleştirmek amacıyla ve dağılımların pozitif yönde yüksek düzeyde çarpıklık göstermesinden dolayı logaritmik dönüşüm uygulanmış (Kalaycı, 2006), dağılım normal hale gelmiştir. Çoklu hiyerarşik regresyon yapılabilmesi için gereken varsayımların sağlanmasında değişkenler arasındaki çoklu ortak doğrusallık kontrol edilmiş, daha sonra uç değerler olup olmadığı incelenmiş ve regresyon varsayımının sağlandığı belirlenmiştir.

\section{Bulgular}

Tablo 1'de betimleyici istatistiklere ilişkin bilgiler verilmiştir.

Tablo 1.Betimsel İstatistikler

\begin{tabular}{lcc}
\hline Değişkenler & $\boldsymbol{X}$ & $\mathbf{S}$ \\
\hline Davranış Problemleri & 35,88 & 5,59 \\
\cline { 2 - 3 } Kavgacı - Saldırgan Olmak & 14,07 & 2,84 \\
Endişeli - Ağlamaklı Olmak & 14,7 & 2,2 \\
Aşırı Hareketli- Dikkatsiz Olmak & 5,96 & 1,85 \\
İstismar Düzeyi & 56.8 & 0.48 \\
\hline
\end{tabular}

Tablo 1 incelendiğinde; çocukların Kavgacı-Saldırgan Olmak alt boyutundan aldıkları ortalama puanın 14,07; Endişeli - Ağlamaklı olmak alt boyutundan aldıkları ortalama puanın 14,7 ve Aşırı Hareketli- Dikkatsiz Olmak alt boyutundan aldıkları ortalama puanın ise 5,96 olduğu görülmektedir. Ölçekten alınabilecek en yüksek puanın 72 olduğu düşünüldüğünde genel olarak çocukların davranış sorunlarının düşük düzeyde olduğu söylenebilmektedir. Ortalama ve standart sapmalar değerlendirildiğinde; en yüksek ortalamanın Kavgacı ve Saldırgan Olmak alt boyutuna ait olduğu ve puan ortalamasının ortalamanın üzerinde olduğu belirlenmiştir.

İstismar Farkındalık Ölçeğinden alınan puanların ortalaması 56,86' dır. Ölçekten alınabilecek en yüksek puan 90 olup; annelerin çocuk istismarı farkındalık düzeylerinin 42-66 puan aralığında olduğu için orta düzeyde 
istismar ifade ettiği söylenebilmektedir. Bu açıdan anneler çocuklarına orta düzeyde istismar uygulamaktadırlar.

Tablo 2. Araştırmaya katılan ebeveynlerin tutumları

\begin{tabular}{lll}
\hline Tutumlar & $\mathbf{n}$ & $\mathbf{\%}$ \\
\hline Demokratik Tutum & 25 & 12 \\
Otoriter Tutum & 176 & 84.6 \\
İin Verici Tutum & 7 & 3.4 \\
Toplam & 422 & 100 \\
\hline
\end{tabular}

Tablo 2'de görüldügü gibi; ebeveynlerin $\% 84.9$ 'unun otoriter, $\% 12$ 'sinin demokratik ve \%3.4'ünün izin verici tutumu diğer tutumlara göre daha yüksek oranda benimsedikleri belirlenmiştir.

Tablo 3. Okul öncesi dönem çocuklarının davranış problemleri ile annelerinin istismar farkındalık düzeyleri ve tutumları arasındaki ilişki

\begin{tabular}{|c|c|c|c|c|c|c|c|c|c|c|}
\hline & & 1 & 2 & 3 & 4 & 5 & 6 & 7 & 8 & 9 \\
\hline \multirow{4}{*}{ 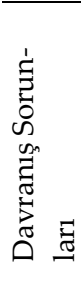 } & 1-Davranış Problemleri & 1 & $.889^{* *}$ & $.701^{* *}$ & $.670^{* *}$ & $.165^{*}$ & $.211^{* *}$ & $-.195^{* * *}$ & .109 & $.165^{*}$ \\
\hline & $\begin{array}{l}\text { 2-Kavgaci - Saldırgan } \\
\text { Olmak }\end{array}$ & $.889^{* *}$ & 1 & $.441^{* *}$ & $.502^{* *}$ & -.042 & $.197^{\text {** }}$ & $-.200^{* *+}$ & .080 & $.166^{*}$ \\
\hline & $\begin{array}{l}\text { 3-Endişeli - Ağlamaklı } \\
\text { Olmak }\end{array}$ & $.701^{* *}$ & $.441^{* *}$ & 1 & $.165^{*}$ & -.083 & .115 & $-.138^{*}$ & .121 & .031 \\
\hline & $\begin{array}{l}\text { 4-Aşırı Hareketli- Dik- } \\
\text { katsiz Olmak }\end{array}$ & $.670^{* *}$ & $.502^{* *}$ & $.165^{*}$ & 1 & -.091 & $.166^{*}$ & -.078 & .056 & $.210^{* *}$ \\
\hline \multirow{4}{*}{ 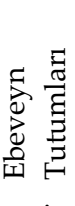 } & $\begin{array}{l}\text { 5-Aşırı Koruyucu Tu- } \\
\text { tum }\end{array}$ & -.082 & -.042 & -.083 & -.091 & 1 & $-.210^{* *}$ & $.476^{* *}$ & $-.331^{* *}$ & -.044 \\
\hline & 6-İzin verici Tutum & $.211^{* *}$ & $.197^{* *}$ & .115 & $.166^{*}$ & $-.210^{* *}$ & 1 & $-.540^{* *+}$ & $.673^{* *}$ & $.178^{*}$ \\
\hline & 7-Demokratik Tutum & $-.195^{* *}$ & $-.200^{* *}$ & $-.138^{*}$ & -.078 & $.476^{* *}$ & $-.540^{* *}$ & 1 & $-.652^{* * *}$ & $-.166^{*}$ \\
\hline & 8-Otoriter Tutum & .109 & .080 & .121 & .056 & $-.331^{* *}$ & $.673^{* *}$ & $-.652^{* *+}$ & 1 & .058 \\
\hline \multicolumn{2}{|c|}{ 9-İstismar Düzeyi } & $.165^{*}$ & $.166^{*}$ & .031 & $.210^{* *}$ & -.044 & $.178^{*}$ & $-.166^{*}$ & .058 & 1 \\
\hline
\end{tabular}

Tablo 3 'te görüldüğü gibi, basit korelasyon analizi sonucunda çocukların davranış problemleri toplamı ile annelerin istismar düzeyleri $(\mathrm{r}=.165 ; \mathrm{p}<.05)$ ve izin verici tutuma sahip olmaları $(\mathrm{r}=.211 ; \mathrm{p}<.001)$ arasinda doğru orantılı, annelerin demokratik tutuma sahip olmaları ( $\mathrm{r}=-.195$; $\mathrm{p}<.001)$ arasında ise negative yönlü bir ilişki bulunmaktadır. Dolayısıyla annelerin istismar düzeyi ve izin verici tutumları arttıkça çocukta davranış problemleri de artmakta ve annenin gösterdiği demokratik tutum arttıkça çocuğun davranış problemleri de azalmaktadır. 
Çocukların cinsiyetlerinin, annelerin istismar farkındalık düzeylerinin ve tutumlarının okul öncesi dönem çocukların davranış problemlerini ne derecede yordadığını belirlemek amacıyla aşamalı çoklu regresyon analizi uygulanmiştır.

Tablo 4. Davranış sorunlarına ilişkin aşamalı çoklu regresyon analizi sonuçları

\begin{tabular}{|c|c|c|c|c|c|c|c|c|}
\hline Yordayıcı Model & B & SHB & $\beta$ & $\mathrm{t}$ & $\mathrm{F}$ & $\mathrm{R}$ & $\mathrm{R}^{2}$ & $\Delta \mathrm{R}^{2}$ \\
\hline (Sabit) & 28.778 & 2.980 & & $9.657^{* *}$ & & & & \\
\hline İstismar Düzeyi & .125 & .052 & .165 & $2.403^{*}$ & 0.775 & .165 & .027 & .023 \\
\hline Sabit & 30.088 & 3.211 & & $9.371^{* *}$ & & & & \\
\hline İstismar Düzeyi & .122 & .052 & .162 & $2.354^{*}$ & 3.486 & .181 & .033 & .023 \\
\hline Aşırı Koruyucu Tutum & -.051 & .047 & -.075 & -1.092 & & & & \\
\hline Sabit & 26.125 & 3.530 & & $7.401^{* *}$ & & & & \\
\hline İstismar Düzeyi & .099 & .052 & .132 & 1.909 & & & & \\
\hline Aşırı Koruyucu Tutum & -.026 & .047 & -.039 & -.558 & 4.550 & .250 & .063 & .049 \\
\hline İzin Verici Tutum & .145 & .057 & .179 & $2.547^{*}$ & & & & \\
\hline Sabit & 31.825 & 6.114 & & $5.205^{* *}$ & & & & \\
\hline İstismar Düzeyi & .094 & .052 & .124 & 1.798 & & & & \\
\hline Aşırı Koruyucu Tutum & .000 & .053 & .000 & .003 & 3.514 & .262 & .065 & .050 \\
\hline İzin Verici Tutum & .108 & .065 & .133 & 1.645 & & & & \\
\hline Otoriter Tutum &,- 039 & 059 &,- 064 &,- 667 & & & & \\
\hline Sabit & 36.757 & 7.259 & & $5.064^{* *}$ & & & & \\
\hline İstismar Düzeyi & .085 & .053 & .112 & 1.609 & & & & \\
\hline Aşırı Koruyucu Tutum & -.004 & .053 & -.006 & -.082 & & & & \\
\hline İzin Verici Tutum & .157 & .076 & .195 & $2.059^{*}$ & 3.318 & .276 & .076 & .053 \\
\hline Otoriter Tutum & -.081 & .064 & -.131 & -1.256 & & & & \\
\hline Demokratik Tutum & -4.921 & 3.153 & -.154 & -1.561 & & & & \\
\hline
\end{tabular}

a. Bağımlı değişken: Okul Öncesi Davranış Problemleri ${ }^{* *} \mathrm{p}<0.01 ;{ }^{*} \mathrm{p}<.05$

Tablo $4^{\prime}$ te $\mathrm{R}^{2}$ değerleri incelendiğinde, ilk aşamada annenin istismar düzeyinin varyansın \% 3'ünü açıkladığı görülmektedir [F(1, 207): 5.775; $\mathrm{p}<.05]$. İkinci aşamada aşırı koruyucu tutum katılmış ve toplam varyans \% 3.3'e [F(2, 207): 3.486; $\mathrm{p}<.05]$; üçüncü aşamada izin verici tutum ile birlikte \% 6.3'e [F(3, 207): 4.550; $\mathrm{p}<.05]$, otoriter tutumun eklenmesiyle beraber \% 6.5'e $[\mathrm{F}(4,207): 3.514 ; \mathrm{p}<.05]$ ve son olarak demokratik tutumla birlikte \%7.6'ya $[F(5,207): 3.318 ; \mathrm{p}<.05]$ yükseldiği belirlenmiştir. Yapılan bu aşamalı çoklu regresyon analizi sonucunda en önemli yordama katkısının izin verici tutum $(\beta=.195)$ olduğu belirlenmiştir. Bu durumda izin verici tutum gösteren ebeveynlerin, çocuklarının davranış problemleri üzerinde etkisi bulunmaktadır. 
Tablo 5. Kavgacı-saldırgan olmak alt boyutuna ilişkin aşamalı çoklu regresyon analizi sonuçları

\begin{tabular}{lcccccccc}
\hline \multicolumn{1}{c}{ Yordayıcı Model } & $\mathrm{B}$ & $\mathrm{SHB}$ & $\beta$ & $\mathrm{t}$ & $\mathrm{F}$ & $\mathrm{R}$ & $\mathrm{R}^{2}$ & $\Delta \mathrm{R}^{2}$ \\
\hline (Sabit) & 1,042 &, 041 &, 166 & $25,21^{*}$ & 5,807 &, 166 &, 027 &, 023 \\
İstismar Düzeyi &, 002 &, 001 & & $2,41^{*}$ & & & & \\
Sabit & 1,050 &, 045 &, 164 & $23,53^{*}$ & & & & \\
İstismar Düzeyi &, 002 &, 001 &,- 035 & $2,38^{*}$ & 3,019 &, 169 &, 029 &, 019 \\
Aşır1 Koruyucu Tutum &, 000 &, 001 & &,- 501 & & & & \\
Sabit &, 997 &, 049 &, 135 & $20,297^{*}$ & & & & \\
İstismar Düzeyi &, 001 &, 001 &, 001 & 1,950 & & & \\
Aşır1 Koruyucu Tutum & 5,44 &, 001 &, 173 &, 008 & 4,063 &, 237 &, 056 &, 043 \\
İzin Verici Tutum &, 002 &, 001 & & $2,450^{*}$ & & & & \\
Sabit & 1,016 &, 053 & & $19,011^{*}$ & & & & \\
İstismar Düzeyi &, 001 &, 001 &, 129 & 1,860 & & & & \\
Aşır1 Koruyucu Tutum &, 000 &, 001 &,- 017 &,- 231 & 3,251 &, 245 &, 060 &, 042 \\
İzin Verici Tutum &, 003 &, 001 &, 229 & $2,445^{*}$ & & & & \\
Otoriter Tutum &,- 001 &, 001 &,- 087 &,- 909 & & & & \\
Sabit & 1,208 &, 100 & & $12,044^{*}$ & & & & \\
İstismar Düzeyi &, 001 &, 001 &, 107 & 1,546 & & & & \\
Assırı Koruyucu Tutum &, 000 &, 001 &, 048 &, 623 & & & & \\
İzin Verici Tutum &, 002 &, 001 &, 192 & $2,042^{*}$ & 3,665 &, 288 &, 083 &, 060 \\
Otoriter Tutum &,- 002 &, 001 &,- 184 & $-1,767$ & & & & \\
Demokratik Tutum &,- 098 &, 044 &,- 221 & $-2,249^{*}$ & & & & \\
\hline
\end{tabular}

a. Bă̆ımlı değişken: Kavgact-Saldırgan Olmak Alt Boyutu ** $p<0.01 ;{ }^{*} p<.05$

Tablo 5'te yer alan aşamalı regresyon analizi sonuçları incelendiğinde; Kavgacı-Saldırgan Olmak alt boyutuna ilişkin II. Modelin anlamlı olmadığ [F(2, 207): 3.019; $p>.05]$ diğer modellerin ise anlamlı olduğu görülmektedir. Bütün değişkenler varyansın \%8.3'ünü açıklamaktadırlar. İlk aşamada girilen annenin istismar düzeyinin varyansın $\% 2.7^{\prime} \operatorname{sini}[\mathrm{F}(1,207)$ : 5.807; $\mathrm{p}<.05$ ]açıkladığı; üçüncü aşamada izin verici tutum ile birlikte $\%$ 5.6'ya[F(3, 207): 4.063; $\mathrm{p}<.05]$, otoriter tutumun eklenmesiyle beraber \% 6.0'a $[\mathrm{F}(4,207): 3.251 ; \mathrm{p}<.05]$ ve son olarak demokratik tutumla birlikte \%8.3'e [F(5, 207): 3.665; p<.05]yükseldiği belirlenmiştir. Yapılan bu aşamalı çoklu regresyon analizi sonucunda en önemli yordama katkısının demokratik tutum $(\beta=.-221)$ ve izin verici tutum $(\beta=.195)$ olduğu belirlenmiştir. $\mathrm{Bu}$ durumda izin verici tutum gösteren ebeveynlerin, çocuklarının kavgacı-saldırgan olmaları üzerinde doğru orantılı, demokratik tutumun ise ters orantılı etkini olduğu görülmektedir. 
Tablo 6. Endişeli-ağlamaklı olmak alt boyutuna ilişkin aşamalı çoklu regresyon analizi sonuçlarn

\begin{tabular}{|c|c|c|c|c|c|c|c|c|}
\hline Yordayıcı Model & $\mathrm{B}$ & SHB & $\beta$ & $\mathrm{t}$ & $\mathrm{F}$ & $\mathrm{R}$ & $\mathrm{R}^{2}$ & $\Delta \mathrm{R}^{2}$ \\
\hline (Sabit) & 1,116 & 120 & & $9,309^{*}$ & \multirow{2}{*}{ 152 } & \multirow{2}{*}{,027 } & \multirow{2}{*}{ 001 } & \multirow{2}{*}{,- 004} \\
\hline İstismar Düzeyi & 0.27 & ,68 & ,027 & ,390 & & & & \\
\hline Sabit & 1,137 & 120 & & $9,391^{*}$ & \multirow{3}{*}{,771 } & \multirow{3}{*}{,086 } & \multirow{3}{*}{,007 } & \multirow{3}{*}{,- 002} \\
\hline İstismar Düzeyi & 023 & ,68 & ,023 & ,332 & & & & \\
\hline Aşırı Koruyucu Tutum &,- 001 & ,001 &,- 082 & $-1,179$ & & & & \\
\hline Sabit & 1,134 & 120 & & $9,389^{*}$ & \multirow{4}{*}{1,164} & \multirow{4}{*}{ 130 } & \multirow{4}{*}{,017 } & \multirow{4}{*}{,002 } \\
\hline İstismar Düzeyi & ,006 & ,69 &, 007 & ,093 & & & & \\
\hline Aşırı Koruyucu Tutum & 000 & ,001 &,- 062 &,- 871 & & & & \\
\hline İzin Verici Tutum & 001 & ,001 & 100 & 1,394 & & & & \\
\hline Sabit & 1,199 & ,123 & & $9,127^{*}$ & \multirow{5}{*}{,978 } & \multirow{5}{*}{,138 } & \multirow{5}{*}{,019 } & \multirow{5}{*}{,000 } \\
\hline İstismar Düzeyi &,- 001 & 070 & ,009 & 132 & & & & \\
\hline Aşırı Koruyucu Tutum & 001 & ,001 &,- 049 & -667 & & & & \\
\hline İzin Verici Tutum & 000 & ,001 &, 060 & 625 & & & & \\
\hline Otoriter Tutum & 1,186 & ,001 &, 064 & 656 & & & & \\
\hline Sabit & 001 & 146 & & $8,106^{*}$ & \multirow{6}{*}{,918 } & \multirow{6}{*}{,149 } & \multirow{6}{*}{,022 } & \multirow{6}{*}{,- 002} \\
\hline İstismar Düzeyi & 000 & ,070 & ,001 & ,016 & & & & \\
\hline Aşırı Koruyucu Tutum & 000 & ,001 &,- 025 &,- 309 & & & & \\
\hline İzin Verici Tutum &, 000 & ,001 &, 045 & ,468 & & & & \\
\hline Otoriter Tutum & ,000 & ,001 & 027 & 256 & & & & \\
\hline Demokratik Tutum &,- 028 &, 034 &,- 084 &,- 828 & & & & \\
\hline
\end{tabular}

Endişeli-Ağlamaklı Olmak alt boyutuna ilişkin yapılan aşamalı çoklu regresyon analizi sonuçlarına göre; ilk aşamada annenin istismar düzeyine yönelik oluşturulan modelin [F(1, 207): .152; p> .05]; ikinci aşamada aşır1 koruyucu tutum katılarak oluşturulan modelin $[\mathrm{F}(2,207)$ : .771; $\mathrm{p}>.05]$; üçüncü aşamada izin verici tutum ile birlikte oluşturulan modelin $[\mathrm{F}(3$, 207): 1.164; $\mathrm{p}>$.05], demokratik tutumun eklenmesiyle beraber oluşturulan modelin $[\mathrm{F}(4,207): .978 ; \mathrm{p}>.05]$ ve son olarak otoriter tutumla birlikte oluşturulan modelin $[\mathrm{F}(5,207): .918 ; \mathrm{p}>.05]$ anlamlı olmadığı belirlenmiştir. Bu durumda annelerin tutumlarının ve istismar düzeylerinin çocukların endişeli-ağlamaklı olmak davranışları üzerinde önemli bir etkisinin olmadığı söylenebilir. 
Tablo 7. Aşırı hareketli-dikkatsiz olmak alt boyutuna ilişkin aşamalı çoklu regresyon analizi sonuçları

\begin{tabular}{|c|c|c|c|c|c|c|c|c|}
\hline Yordayıcı Model & $\mathrm{B}$ & SHB & $\beta$ & $\mathrm{t}$ & $\mathrm{F}$ & $\mathrm{R}$ & $\mathrm{R}^{2}$ & $\Delta \mathrm{R} 2$ \\
\hline (Sabit) & 2.979 & .975 & & $3.056^{*}$ & \multirow{2}{*}{9.495} & \multirow{2}{*}{.210} & \multirow{2}{*}{.044} & \multirow{2}{*}{.039} \\
\hline İstismar Düzeyi & .052 & .017 & .210 & $3.081^{*}$ & & & & \\
\hline Sabit & 3.450 & 1.049 & & $3.287^{*}$ & \multirow{3}{*}{5.480} & \multirow{3}{*}{.225} & \multirow{3}{*}{.051} & \multirow{3}{*}{.041} \\
\hline İstismar Düzeyi & .051 & .017 & .206 & $3.029^{*}$ & & & & \\
\hline $\begin{array}{l}\text { Aşırı Koruyucu } \\
\text { Tutum }\end{array}$ & -.018 & .015 & -.082 & -1.202 & & & & \\
\hline Sabit & 2.568 & 1.164 & & $2.207^{*}$ & \multirow{4}{*}{4.673} & \multirow{4}{*}{.254} & \multirow{4}{*}{.064} & \multirow{4}{*}{.051} \\
\hline İstismar Düzeyi & .046 & .017 & .186 & $2.701^{*}$ & & & & \\
\hline $\begin{array}{l}\text { Aşırı Koruyucu } \\
\text { Tutum }\end{array}$ & -.013 & .016 & -.057 & -.827 & & & & \\
\hline İzin Verici Tutum & .032 & .019 & .121 & 1.719 & & & & \\
\hline Sabit & 3.133 & 1.265 & & $2.478^{*}$ & \multirow{5}{*}{3.832} & \multirow{5}{*}{.265} & \multirow{5}{*}{.070} & \multirow{5}{*}{.052} \\
\hline İstismar Düzeyi & .045 & .017 & .179 & $2.590^{*}$ & & & & \\
\hline $\begin{array}{l}\text { Aşırı Koruyucu } \\
\text { Tutum }\end{array}$ & -.018 & .016 & -.079 & -1.098 & & & & \\
\hline İzin Verici Tutum & .051 & .025 & .190 & $2.043^{*}$ & & & & \\
\hline Otoriter Tutum & -.022 & .019 & -.108 & -1.136 & & & & \\
\hline Sabit & 2.169 & 2.401 & & .903 & \multirow{6}{*}{3.099} & \multirow{6}{*}{.267} & \multirow{6}{*}{.071} & \multirow{6}{*}{.048} \\
\hline İstismar Düzeyi & .046 & .017 & .183 & $2.626^{*}$ & & & & \\
\hline $\begin{array}{l}\text { Aşırı Koruyucu } \\
\text { Tutum }\end{array}$ & -.021 & .018 & -.092 & -1.193 & & & & \\
\hline İzin Verici Tutum & .053 & .025 & .198 & $2.090^{*}$ & & & & \\
\hline Otoriter Tutum & -.018 & .021 & -.088 & -.835 & & & & \\
\hline $\begin{array}{l}\text { Demokratik Tu- } \\
\text { tum }\end{array}$ & .493 & 1.043 & .047 & .473 & & & & \\
\hline
\end{tabular}

a. Bă̆ımlı değiş̧ken: Aşııı Hareketli-Dikkatsiz Olmak Alt Boyutu ** $p<0.01 ;{ }^{*} p<.05$

Tablo 7'de $\mathrm{R}^{2}$ değerleri incelendiğinde, Aşırı Hareketli-Dikkatsiz Olmak alt boyutuna ilişkin I. Modelin varyansın \%4.4'ünü açıkladığ1 görülmektedir [F(1, 207): 9.495; $\mathrm{p}<.05]$. Aşırı koruyucu tutumla beraber toplam varyans \% 5.1'e [F(2, 207): 5.480; $\mathrm{p}<.05]$; izin verici tutum ile birlikte $\%$ 6.4'e $[\mathrm{F}(3,207): 4.673 ; \mathrm{p}<.05]$, demokratik tutumun eklenmesiyle beraber \% 7'ye [F(4,207): 3.832; $\mathrm{p}<.05]$ ve son olarak otoriter tutumla birlikte \%7.1"e [F(5, 207): 3.099; p< .05] yükseldiği belirlenmiştir. Yapılan bu aşamalı çoklu regresyon analizi sonucunda en önemli yordama katkısının izin verici tutum $(\beta=.195)$ ve annenin istismar düzeyi $(\beta=.183)$ olduğu be- 
lirlenmiştir. Bu durumda izin verici tutumun ve annenin istismar düzeyinin çocuklarının aşırı hareketli ve dikkatsiz olmaları üzerinde etkisi bulunmaktadir.

\section{Tartışma, Sonuç ve Öneriler}

$\mathrm{Bu}$ araştırmada okul öncesi dönemde çocuğa sahip annelerin ebeveyn tutumları ve istismar düzeyleri ile çocuklarının davranış sorunları arasındaki ilişkinin incelenmesi amaçlanmıştır. Araştırma sonucunda çocukların davranış problemlerine ilişkin toplam puan ile annelerin istismar düzeyleri ve izin verici tutuma sahip olmaları arasında pozitif yönlü, annelerin demokratik tutuma sahip olmaları arasında ise negatif yönlü bir ilişki bulunduğu saptanmıştır. Yapılan bir araştırma sonucunda da ebeveyn tutumlarının çocuklarının davranış problemleri ile ilişkili olduğu belirlenmiştir (Yurduşen, Erol ve Gençöz, 2013).Yapılan çalışmalar ebeveyn tutumları ve çocukların davranış problemleri arasında ilişki olduğunu ve ebeveynlerin çocuklarıyla yeterli düzeyde ilgilenmemelerinin de çocukların davranış sorunları göstermesi ile ilişkili olduğunu göstermektedir (Aunola ve Nurmi, 2005; Aydoğdu ve Dilekmen, 2016; Benzies, Keown ve MagillEvans, 2009; Huntsinger ve Rose, 2009; Öngider, 2013; Waller, Gardner, Hyde, Shaw, Dishion ve Wilson, 2012). Park vd. (2018) de ebeveynlerin çocuklarına gösterdikleri olumlu davranışların çocukların davranışlarına olumlu yansıdığını ifade etmektedir. Ayrıca bu araştırma sonucunda çocukların davranış problemlerinin ebeveynlerin istismar düzeyleri ile ilişkisi olduğu belirlenmiştir. Milaniak ve Widom (2015) da 011 yaş arasında fiziksel ve cinsel istismara uğramış ve uğramamış en fazla 29 yaşında olan bireylerle yaptıkları araştırma sonucunda, istismarın suç işlemeyi doğrudan etkilediğini belirlemişlerdir. Ayrıca annelerin demokratik tutum davranışları arttıkça istismar düzeylerinin ve çocuklarının davranış problemlerinin azaldığı belirlenmiştir. Bu durumda çocukların olumlu davranışlar geliştirmesinin annelerinin demokratik tutum sergilemesiyle ilişkili olduğu söylenebilir.

Araştırma sonucunda; izin verici tutum gösteren ebeveynlerin, çocuklarının davranış problemleri, kavgacı-saldırgan olmaları ve aşırı hareketli ve dikkatsiz olmaları üzerinde etkisi bulunduğu belirlenmiştir. İzin verici 
tutuma sahip ebeveynlerin çocuklarının kendini daha az kontrol eden bireyler oldukları ifade edilmektedir (Papalia ve Feldman, 2011).Okul öncesi dönemde çocuğun davranışlarına tepki gösterilmemesi, çocuğun girdiği her ortamda aynı tutumları aramasına ve istediği davranış ile karşılaşmadığında tedirginlik ve huzursuzluk yaşayarak davranış sorunları göstermesine sebep olmaktadır (Aydoğdu ve Dilekmen, 2016). Dolay1sıyla izin verici anne tutumuna sahip olan bu çocuklar, istedikleri ortam onlara sağlanmadığı için davranış problemleri göstermektedirler. Yapılan bu çalışmadan farklı olarak; İkiz, Otlu ve Ekinci Vural (2016) öğretmenlerle çocuklarda görülen davranış problemleri üzerine yaptıkları araştırma sonucunda; davranış problemlerini etkileyen ailesel faktörlerden birinin aşırı koruyucu ebeveynler olduğunu belirlemişlerdir. Çocukların mizaç özellikleri ile ebeveyn tutumlarını inceleyen bir araştırmada ile düşük düzeyde kontrollü, engellenmeye yatkın olan çocukların olumsuz ebeveyn tutumlarından etkilendikleri ve ebeveynlerin de çocukların bu mizacından dolayı olumsuz tutumlarını arttırdıkları belirlenmiştir (Lengua ve Zalewski, 2011). Bu araştırma sadece çocukların davranış sorunları ile annelerin istismar düzeyleri ve ebeveyn tutumları arasındaki ilişkiyi incelemeyi amaçlamıştır. Çocukların karakter ve mizaç özellikleri gibi farklı değişkenlerin de ele alınmasının bu araştırma sonuçlarını daha da güçlendireceği düşünülmektedir.

Ayrıca bu araştırma sonucunda demokratik tutumun çocukların kavgacı-saldırgan olmaları ile ters orantılı etkiye sahip olduğu belirlenmiştir. Yapılan çalışmalar demokratik tutuma sahip olan annelerin çocuklarının sosyal ve duygusal uyum düzeylerinin yüksek olduğunu ifade etmektedir (Demir, Karabay ve Ası, 2017; Gülay ve Önder, 2011 ). Dolayısıyla demokratik tutuma sahip ebeveynlerin çocuklarının davranış sorunları göstermeyen ve daha uyumlu çocuklar olarak yetiştikleri düşünülmektedir.

Annenin istismar düzeyinin ise çocuklarının aşırı hareketli ve dikkatsiz olmaları üzerinde etkisi bulunduğu saptanmıştır. Ancak bu araştırma sonucunda annelerin tutumlarının ve istismar düzeylerinin çocukların endişeli-ağlamaklı olmak davranışları üzerinde önemli bir etkisinin olmadığı belirlenmiştir. İstismarın davranış problemleri, düşük benlik saygısı, suça eğilim, depresyon gibi olumsuz sonuçları olduğu bilinmektedir (Kaya, Çeçen-Eroğlu, 2013). Çocukların aile içinde istismara maruz kalmalarını; çocuğun aşırı hareketli olması, ebeveynden birinin uyuşturucu, 
alkol bağımlısı olması, engelli ve süreğen hastalığı olması, duygusal sorunlu olması, stresli iş yaşamının olması, ebeveyn ile çocuk arasındaki sağlıksız etkileşim, istenmeyen gebelik ve çocuğun gelişimsel sorunlarının olması gibi nedenler etkilemektedir. Ayrıca çocuğun geniş aile yapısında ya da parçalanmış ailede yetişmesi, mutsuz bir evlilik ortamında büyümesi, yoksulluk faktörleri ve anne babanın kendi çocukluğunda istismarı yaşamış olması da istismarın oluşmasını etkileyen etmenlerdir (Güler, Uzun, İşiten, Ülker, Öner, 2002; Gürhan, 2015; Kara Doruk, 2012; Öncü, Kurt ve Esenay, 2012; Pekdoğan ve Kanak, 2017; Polat, 2007; Svensson, Bornehag ve Janson, 2011; Ünal, 2008). Dolayısıyla çocuğun aşırı hareketli ve dikkatsiz olmasının annenin istismar düzeyi üzerinde etkisinin olması yapılan önceki çalışmalarla paralellik göstermektedir. Yapılan bu araştırma sonucunda her ne kadar izin verici tutumun davranış sorunları üzerinde etkisi olduğu belirlenmiş olsa da etki oranının düşük olduğu da görülmektedir. Öğretmen, medya, aile içi yaşantılar, baba faktörü, kalıtımsal nedenler, annenin çalışma durumu, eğitim durumu, çocuğun yaşı, cinsiyeti gibi faktörlerin de çocukların davranış problemleri üzerinde etkisi olduğu belirtilmektedir (Alisinanoğlu ve Kesicioğlu, 2010; Kanlıkılıçer, 2005). Bu çalışmada sadece annelerin istismar düzeyleri ve ebeveyn tutumları ile çocukların davranış sorunları arasındaki ilişki incelenmiştir. Cinsiyet, anne yaşı, baba yaşı, baba eğitim durumu, anne eğitim durumu gibi değişkenlerin istismar ve ebeveyn tutumlarının birer etkeni olduğu düşünüldüğünde; yapılacak olan yeni çalışmalarda bu faktörlerin de ele alınmasının faydalı olacağı düşünülmektedir. Ayrıca bu araştırma kapsamına alınan annelerin istismar düzeylerinin orta düzeyde olması çalışmanın bir sınırlılı̆̆ı olarak görülmektedir. Yüksek düzeyde istismarın özellikle davranış sorunları konusunda daha açıklayıcı olacağı düşünülmektedir. Ayrıca özellikle fiziksel istismar hala günümüzde disipline etmek için kullanılan bir yöntem (Özgentürk, 2014) olduğu için, annelerin aşırı hareketli olan çocuklarını bu şekilde bastırılabildikleri düşünülmektedir. Lansford, Godwin, Tirado ve diğerleri (2015) dokuz ülkede ve 13 farklı grupta yaptıkları bir araştırmada fiziksel istismarda ebeveynin tutumunun ve fiziksel cezaya yönelik olarak toplumun bakış açısının önemli birer faktör olduğunu belirlemişlerdir. Bu araştırma Bursa ili merkez ilçelerinde yaşayan anneler ve çocuklar ile yapılmıştır. Araştırmanın farklı bölge- 
lerde farklı kültürlerden gelen ailelerle yapılmasının ve araştırma kapsamına babaların da alınmasının araştırmanın toplum geneline yaygınlaştırılması açısından önemli olduğu düşünülmektedir.

Bu çalışmada annelerin istismar farkındalıkları ile tutumlarının çocuklarının davranış sorunları ile ilişkisi incelenmiştir. Annelerin ebeveyn tutumlarının otoriter tutumda yoğunlaştığ zeyde olduğu belirlenen bu çalışmada, her ne kadar çocukların davranış sorunları düşük düzeyde çıkmış olsa da, üç değişken arasında ilişkinin olduğu söylenebilmektedir. Bu nedenle yönelik olarak çocukta davranış sorunlarının oluşumunu önleyici nitelikte çalışmalar yapılıp, önleyici programlar oluşturulup deneysel araştırmaların yapılmasının, sorunların en aza indirilmesinde önemli olduğu düşünülmektedir. Ayrıca öğretmen ve velilerle görüşme yapılarak bu konuyla ilgili daha detaylı sonuçların elde edilebileceği düşünülmektedir. 
EXTENDED ABSTRACT

\title{
The Relation Between the Abuse Levels of Mothers, Parental Attitudes and Behavioural Problems of Children *
}

\author{
Pınar Bağçeli Kahraman - Ayşe Çubukcu \\ Bursa Uludăg University
}

Within the study it is aimed to investigate the relation between the behaviour problems of the children and the abuse levels of the mothers with parental attitudes. Based on the common idea in our country that mothers are considered as the person who cares and is responsible for the education of the children more, only mothers were included in the research. It is thought that within the preschool period especially the behaviours of the mothers cause the children's behavioural problems. It is thought that the determination of the relation between the children's behavioural problems and mothers' attitudes with abuse levels will contribute to the decrease of the behavioural problems and prevent these behaviours in early period. Accordingly it is aimed to determine the relation between the children's behavioural problems and the attitudes of the mothers with their abuse levels.

In this research, which is carried out with the purpose of determining the predicting effect of the mothers' abuse levels and attitudes on children's behavioural problems, correlational research was used. The study group of the research consists of totally 208 children, who were chosen with the appropriate sampling method among children at 60-72 months and attend seven different public preschools in the central districts of Bursa city, and the mothers of these children. Within the research personal information form, "Preschool Behavioural Problems Scanning Scale" which was developed by Behar (1976) and adapted into Turkish by Kanlikilicer (2005) and also "Abuse Awareness Scale: Parent Form" which was developed by Pekdogan (2017) and "Parent Attitude Scale" which was developed by Demir and Sendil (2008) were used.

Within this research, descriptive analysis methods were utilized. In order to determine the variables of the mothers' abuse levels and attitudes, 
the behavioural problems which are dependent variable and their sub dimensions ideally multi hierarchical regression analysis was performed.

As a result of the research it was determined that there was a positive relation between children's behavioural problems and mothers abuse levels along with their having permissive attitude; and a negative relation between mothers' having democratic attitude. Also in this research it was determined that there is a relationship between mothers' parental attitudes and children's behavioural problems.

As a result of the research; it was determined that the parents, who have permissive attitude, affect the children's behavioural problems, being combative-aggressive, hyperactive and inattentive. It is stated that the children of the parents, who have permissive attitude, are the individuals who control themselves less (Papalia \& Feldman, 2011). Not showing reaction to the behaviours of the children in the preschool period cause the children look for the same attitude in the environments they appear and indicate behavioural problems, unease and disturbance when they do not encounter the behaviours they expect (Aydogdu \& Dilekmen, 2016). Accordingly these children who have permissive mother attitude show behavioural problems since they are not provided the environment they desire. Different from this research, as a result of the research, which was carried out by Ikiz, Otlu and Ekinci Vural (2016) with teachers on the behavioural problems seen in the children, it was determined that one of the family factors that affect behavioural problems is the over protective parents. In a research in which the characters of the children and the parental attitudes are surveyed it was determined that the children controlled at low level, have tendency to be prohibited are affected by negative parental attitudes and the parents increase their negative attitude because of the character of the children (Kiff,Lengua\& Zalewski, 2011).This research only aims to investigate the relation between children's behavioural problems and mothers' abuse levels with their parental attitude. It is thought that discussing the different variables such as character and temperament features of the children would strengthen the results of this research. In addition as a result of this research it was determined that democratic attitude has negative effect on the children's being combative-aggressive. The studies performed assert that the children, whose mothers have democratic attitude, possess high social adaptation levels (Demir, Karabay \& 
Asi, 2017; Gulay \& Onder, 2011). Accordingly the children of the parents, who have democratic attitude, are raised as children who are more easygoing and do not have behavioural problems.

As a result of this research although it is determined that permissive attitude has an effect on behavioural problems it is seen that the effect rate is low. It is stated that the factors like teacher, media, family experiences, father factor, genetic reasons, mother's working situation, education status, the age of the child and gender have an effect on the behavioural problems (Alisinanoglu \& Kesicioglu, 2010; Kanlikiliçer, 2005). Within this study only the relation between children's behavioural problems and mothers' abuse levels together with their parental attitudes was investigated. Considering the fact that variables such as mother age, father age, father education status, mother education status are one of the factors of the abuse and parental attitudes; it is thought that discussing these factors in further studies would be useful. In addition the abuse levels of mothers, who participated in this research, being at the medium level is considered as a constraint of this study. It is thought that abuse levels at high levels would be more explanatory especially in terms of behavioural problems.

This research was carried out with the mothers and the children who live in central provinces in Bursa. It is thought that performing the research with the families coming from different cultures and regions and including the fathers within the scope of the research would be important in terms of generalizing the research in society.

In accordance with this study determining the mothers' attitudes and abuse levels the relation between children's behavioural problems were investigated. Within this study in which it was found that mothers' parental attitudes centre around authoritarian attitude, abuse levels were determined to be at medium level, although behavioural problem levels of the children were found at low level, it can be said that there is a relation between these three. Therefore it is thought that performing preventive programs, experimental researches and studies that prevent the emerging of the children's behavioural problems would be important in decreasing the number of these problems. In addition it is thought that having interviews with the teachers and the parents more detailed results can be obtained concerning this issue. 


\section{Kaynakça / References}

Akman, B., Akyol, G.,Arslan, T., Çelik-Kükütçü, A. ve S., Kent (2011). Okul öncesi öğretmenlerinin sınıfta karşılaştıkları sorun davranışlara ilişkin düşünceleri. E-Journal Of New World Sciences Academy Education Sciences, 6 (2), 1715-1731.

Alabay, E. (2017). Okul öncesi dönem çocuğu olan ebeveynlerin ebeveynlik tutumlarının incelenmesi. Erken Çocukluk Çalışmaları Dergisi, 1(2), 156-174

Alisinanoğlu, F. ve Kesicioğlu, O. S. (2010). Okul öncesi dönem çocuklarının davranış sorunlarının çeşitli değişkenler açısından incelenmesi (Giresun ili örneği). Kuramsal Ĕ̆itim Bilim Dergisi, 3 (1), 93110.

Atabey, D. (2017). Anasınıfına devam eden çocukların annelerinin anne tutumlarının incelenmesi (Çorum ili örneği). Hitit Üniversitesi Sosyal Bilimler Enstitüsü Dergisi, 10 (1), 145-168

Aunola, K., ve Nurmi, J. E. (2005). The role of parenting styles in children's problem behavior. Child development, 76(6), 1144-1159.

Aydoğdu, F. ve Dilekmen, M. (2016). Ebeveyn tutumlarının çeşitli değişkenler açısından değerlendirilmesi. Bayburt Eğitim Fakültesi Dergisi, 11(2), 569-585.

Baumrind, D. (1971). Harmonious parents and their preschool children. Developmental Psychology, 4, 99-102

Benzies, K., Keown, L. A., ve Magill-Evans, J. (2009). Immediate and sustained effects of parenting on physical aggression in Canadian children aged 6 years and younger. The Canadian Journal of Psychiatry, 54(1), 55-64.

Berk, L.E (2009). Child development (8th ed). Boston : Pearson

Bernard vanLeer Vakfı (2014). Türkiye'de 0-8 yaş arası çocuğa yönelik aile içi şiddet araştırması. İstanbul. http://www.ailecocuksiddet.info-/RAPOR.pdf adresinden erişildi.

Bronfenbrenner, U. (1979). The ecology of human development. Harvard University Press.

Budak, S. (2017). Psikoloji Sözlüğ̈̈̈. Ankara: Bilim Sanat Yayınları. 
Büküşoğlu N, Aysan F ve Erermiş S. (2001). Okul fobisi olan çocukların davranışsal özellikleri, annelerinin ruhsal belirti düzeyleri ve aile fonksiyonlarının incelenmesi. Ege Tip Dergisi, 40, 99-104.

Büyüköztürk, S., Kiliç Çakmak, E., Akgün, Ö. E., Karadeniz, S. ve Demirel, F. (2012). Bilimsel araştırma yöntemleri (18. Baskı). Ankara: Pegem Akademi Yayımcilı.

Caldarella, P. ve Merrll, K.W.(1997). Common dimensions of social skills of children and adolescents: A taxonomy of positive behaviors. School Psychology Rewiew,26 (2), 264-268.

Cenk, S.D. ve Demir, A. (2015). The relationship between parenting style, gender and academic achievement with optimism among turkish adolescents. Current Psychology, 9(35), 720-728.

Çebi, S. (2017).60-72 aylık çocukların davranış sorunlarını ve kendilik algılarını etkileyen faktörlerin incelenmesi. Yayımlanmamış yüksek lisans tezi, Okan Üniversitesi Sosyal Bilimler Enstitüsü, İstanbul

Demir, T. Karabay, Ş. O. ve Ası, D.,Ş. (2017). 5 yaş çocuklarının sosyal duygusal uyumları ile ebeveynlerinin tutumları arasındaki ilişki. Disiplinlerarası Ĕ̆itim Araştırmaları Dergisi, 1(2), 1-14.

Dereobalı, N., Karadağ, S. Ç. ve Sönmez, S. (2013). Okul öncesi eğitim öğretmenlerinin çocuk istismarı ihmali şiddet ve eğitimcilerin rolü konusundaki görüşleri. Ege Eğitim Dergisi, 14(1), 50-66.

Derman-Taner, M. ve Başal, H.,A. (2013). Okul öncesi çocuklarında gözlenen davranış problemleri ile ailelerinin anne-baba tutumları arasındaki ilişki. Amasya Üniversitesi Ĕ̆itim Fakültesi Dergisi, 2(1), 115144.

Erkan, S. (2010). Aile ve aile eğitimi ile ilgili temel kavramlar. Z. Fulya Temel (Ed.). İcinde: Aile Ĕ̆itimi Ve Erken Çocukluk Döneminde Aile Katılım Çalışmaları, 1-48, 1. Baskı. Ankara: Anı Yayıncılık.

Fluori E., Tzavidis N. ve Kallis C. (2009). Adverse life events, area socioeconomic disadvantage, and psychopathology and resilience in young children: the importance of risk factors' accumulation and protective factors' specificity. Eur Child Adolesc Psychiatry,19(6), 535-46

Gimpel, G. A., Peacock, G. G., ve Holland, M. L. (2003). Emotional and behavioral problems of young children: Effective interventions in the preschool and kindergarten years. Guilford Press. 
Grusec, J. E., Danyliuk, T., Kil, H., ve O'Neill, D. (2017). Perspectives on parent discipline and child outcomes. International Journal of Behavioral Development, 41(4), 465-471.

Gülay, H. ve Önder, A. (2011). Annelerin tutumlarına göre 5-6 yaş çocuklarının sosyal-duygusal uyum düzeyleri. Celal Bayar Üniversitesi Eğitim Fakültesi Dergisi, 1, 89-105.

Güler, N., Uzun, S., Boztaş, Z. ve Aydoğan, S. (2002). Anneleri tarafından çocuklara uygulanan duygusal ve fiziksel istismar/ihmal davranışı ve bunu etkileyen faktörler. Cumhuriyet Üniversitesi Tıp Fakültesi Dergisi, 24(3), 128-134.

Gürhan N (2015) Her yönüyle çocuk istismar ve ihmali (sağllk-yasa-eğitim ve aile boyutu). Ankara: Nobel Tip Kitabevi.

Huntsinger, C. S., ve Rose, P. S. (2009). Relations among parental acceptance and control and children's social adjustment in Chinese American and European American families. Journal of Family Pyschology, 23, 321-330.

İkiz, F. E., Bahar, M. ve Vural, D. E. (2016). Erken çocukluk döneminde görülen problem davranışlar: öğretmenlerin değerlendirmesi. Mehmet Akif Ersoy Üniversitesi Sosyal Bilimler Enstitüsü Dergisi, 8(17), 216-229.

Kalaycı, S. (2006). SPSS uygulamalı çok değiş̧kenli istatistik teknikleri. Ankara: Asil Publishing.

Kanlıkılıçer, P. (2005). Okul öncesi davranış sorunları tarama ölçĕ̆i: Geçerlilik güvenirlik çalışması. Yayımlanmamış yüksek lisans tezi, Marmara Üniversitesi Eğitim Bilimleri Enstitüsü, İstanbul.

Kargı, E. ve Erkan, S. (2004). Okul öncesi dönem çocuklarının sorun davranışlarının incelenmesi. Hacettepe Üniversitesi Ĕ̆itim Fakültesi Dergisi, 27, 135-144.

Kaya, A. , Bozaslan, H. ve Genç, G. (2012). Üniversite öğrencilerinin annebaba tutumlarının problem çözme becerilerine, sosyal kaygı düzeylerine ve akademik başarılarına etkisi. Dicle Üniversitesi Ziya Gökalp Ĕ̆itim Fakültesi Dergisi, 18, 208-225.

Kaya İ, Çeçen-Eroğul A.R. (2013). Ergenlerde çocukluk dönemi istismar yaşantılarının yordayıcısı olarak aile işlevlerinin rolü. Ĕğitim ve Bilim, 38(168), 386-397. 
Keser, N., Odabaş, E. ve Elibüyük, S. (2010). Ana-babaların çocuk istismarı ve ihmali konusundaki bilgi düzeylerinin incelenmesi. Türkiye Çocuk Hastalıkları Dergisi, 4(3), 150-157.

Kiff, C. J., Lengua, L. J., ve Zalewski, M. (2011). Nature and nurturing: Parenting in the context of child temperament. Clinical child and family psychology review, 14(3), 251-301. Retrieved from https://link.springer.com/article/10.1007/s10567-011-0093-4 on 11.09.2018.

Köyceğiz, M. ve Özbey, S. (2018). Okul öncesi dönem çocuğu olan ebeveynlerin çatışma eğilimleri ile çocuklarının sosyal becerileri ve problem davranışları arasındaki ilişkinin incelenmesi. Uluslararası Sosyal Araştırmalar Dergisi, 11(55), 655-669.

Lansford, J. E., Godwin, J., Tirado, L. M. U., Zelli, A., Al-Hassan, S. M., Bacchini, D., ... ve Di Giunta, L. (2015). Individual, family, and culture level contributions to child physical abuse and neglect: A longitudinal study in nine countries. Development and psychopathology, 27(4pt2), 1417-1428.

Leetch, A. N., ve Woolridge, D. (2013). Emergency department evaluation of child abuse. Emergency Medicine Clinics, 31(3), 853-873.

Levey, E. J.,Gelaye, B., Bain, P., Rondon, M. B., Borba, C. P., Henderson, D. C. ve Williams, M. A. (2017). A systematic review of randomized controlled trials of interventions designed to decrease child abuse in high-risk families. Child abuse ve neglect, 65, 48-57.

Milaniak, I., ve Widom, C. S. (2015). Does child abuse and neglect increase risk for perpetration of violence inside and outside the home?. Psychology of Violence, 5(3), 246-255.

Öngider, N. (2013). Anne-baba ile okul öncesi çocuk arasındaki ilişki. Psikiyatride Güncel Yaklaşımlar, 5(4), 420-440.

Özbey, S. ve Alisinanoğlu, F. (2009). Okul öncesi eğitim kurumuna devam eden 60-72 aylık çocukların problem davranışlarının bazı değişkenlere göre incelenmesi. Uluslararası Sosyal Araştırmalar Dergisi, 2(6), 493-517.

Özerk, H. (2006). Ana babaların çocuk yetiştirmeye ilişkin tutumlarının, bilgi düzeylerinin ve 11-18 yaş grubu öğrencilerin kendilerini değerlendirmelerinin incelenmesi. Yayımlanmamış yüksek lisans tezi, Ankara Üniversitesi Eğitim Bilimleri Enstitüsü, Ankara 
Özgentürk, İ. (2014). Child abuse and neglect. Journal Of Human Sciences, 11(2), 265-278.

Özyürek, A. ve Şahin, F. T. (2005). 5 ve 6 yaş grubunda çocuğu olan ebeveynlerin tutumlarının incelenmesi. Gazi Üniversitesi Gazi Ĕ̆itim Fakültesi Dergisi, 25(2), 395-414.

Papalia, D. E. ve Feldman, R. D. (2011). A child's WorldI nfancy Through Adolescence. (Twelfth Ed.), New York: Mc Graw Hill Connect Learn Succeed.

Park, J. L., Johnston, C., Colalillo, S., ve Williamson, D. (2018). Parents' attributions for negative and positive child behavior in relation to parenting and child problems. Journal of Clinical Child ve Adolescent Psychology, 47(sup1), 63-75.

Pekdoğan, S. (2017). İstismar farkındalık ölçeği ebeveyn formu: Ölçek geliştirme çalışması. Akademik Bakış Dergisi, 62, 174-185.

Pekdoğan, S. ve Kanak, M. (2017). 4-6 yaş çocuğa sahip annelerin istismar düzeylerinin kadının çalışması ve algılanan cinsiyet rolleri ile olan ilişkisinin incelenmesi. Journal of International Social Research, 10(48), 510-516.

Polat, O. (2007). Tüm boyutlarıyla çocuk istismarı 1. Ankara: Seçkin Yayınc1lik.

Santrock, J. W. (2015). Life-span development. Ankara: Nobel Publishing.

Svensson, B.,Bornehag, C. ve Janson, S. (2011). Chronic conditions in children increase the risk for physical abuse-but vary with socio-economic circum stances. Acta Paediatrica. 100, 407-412.

Şahin, F. T. ve Özyürek, A. (2008). 5-6 yaş grubu çocuğa sahip ebeveynlerin demografik özelliklerinin çocuk yetiştirme tutumlarına etkisinin incelenmesi. Türk Eğitim Bilimleri Dergisi, 6(3), 395-414

Şendil, G. ve Demir, K. E. (2008). Ebeveyn tutum ölçeği. Türk Psikoloji Yazllarl, 11(21), 15-25.

Tarkoçin, S. (2014). Okul öncesi eğitim kurumuna devam eden 48-66 aylık çocukları olan ebeveynlerin çocuklarn ile iletişim kurma düzeyleri ve davranış sorunları arasındaki ilişkinin incelenmesi. Yayımlanmamıs yüksek lisans tezi, Marmara Üniversitesi Eğitim Bilimleri Enstitüsü, İstanbul. 
UNICEF (2010). Türkiye'de çocuk istismarı ve aile içi şiddet araştırması özet rapor. Başbakanlık Sosyal Hizmetler ve Çocuk Esirgeme Kurumu. Ankara

Uyanık, Ö., İnal Kızıltepe, G., Özsüer, S. ve Can Yaşar, M. (2013). 61-72 aylık çocukların demokratik tutum ve davranışlarının anne görüşlerine göre değerlendirilmesi. Türkiye Sosyal Araştırmalar Dergisi, 17(3), 227-243.

Ünal, F. (2008). Ailede çocuk istismarı ve ihmali. TSA Dergisi. 1, 9-18.

Waller, R.,Gardner, F., Hyde, L. W., Shaw, D. S., Dishion, T. J. ve Wilson, M. N. (2012). Do harsh and positive parenting predict parent reports of deceitful - callous behavior in early childhood? Journal of Child Psychology and Psychiatry, 53 (9), 946- 953.

WHO (2002). Dünya Sağllk Örgütü. http://www.who.int/violence_injury _prevention/iolence/child/en/ adresinden erişildi.

Yalçın, H., Koçak, N. ve Duman, G. (2014). Anne babaların çocuk istismaryyla ilgili tutumlarının incelenmesi. Karamanoğlu Mehmetbey Üniversitesi Sosyal Ve Ekonomik Araştırmalar Dergisi, 3, 137-143.

Yılmaz, G., İşiten, N., Ertan, Ü. ve Öner, A. (2003). Bir çocuk istismarı vakası. Çocuk Sağhlğı ve Hastalıkları Dergisi, 46(4), 295-302.

Yoleri, S., Isikoglu Erdogan, N. ve Tetik, G. (2017). Ebeveyn Tutumlarının okul öncesi dönemdeki çocukların mizaç özellikleri ile ilişkisinin incelenmesi. Mehmet Akif Ersoy Üniversitesi Eğitim Fakültesi Dergisi, 42, 226-249.

Yurdeşen, S., Erol, N. ve Gençöz, T. (2013). The effects of parental attitudes and mothers' psychological well-being on the emotional and behavioral problems of their preschool children. Matern Child Health, 17, 68-75.

\section{Kaynakça Bilgisi / Citation Information}

Bağçeli-Kahraman, P. ve Çubukçu, A. (2019). Okul öncesi dönem çocuklarının annelerinin istismar düzeyleri, ebeveyn tutumları ve çocuklarının davranış problemleri arasındaki ilişki. OPUSUluslararası Toplum Araştırmaları Dergisi , 10(17), 1304-1331. DOI: 10.26466/opus.507909 